\title{
Bacterial and viral abundance in Ross Sea summer pack ice communities
}

\author{
Marcia M. Gowing ${ }^{1,6, *}$, David L. Garrison ${ }^{1,3}$, Angela H. Gibson ${ }^{1}$, \\ Jonathan M. Krupp ${ }^{2}$, Martin O. Jeffries ${ }^{4}$, Christian H. Fritsen ${ }^{5}$ \\ ${ }^{1}$ Institute of Marine Sciences, and ${ }^{2}$ Microscopy and Imaging Laboratory, University of California, \\ Santa Cruz, California 95064, USA \\ ${ }^{3}$ Division of Ocean Sciences, National Science Foundation, 4201 Wilson Boulevard, Arlington, Virginia 22230, USA \\ ${ }^{4}$ Geophysical Institute, University of Alaska Fairbanks, Fairbanks, Alaska 99775, USA \\ ${ }^{5}$ Desert Research Institute, Division of Earth and Ecosystem Sciences, Reno, Nevada 89512, USA \\ ${ }^{6}$ Present address: 11513 Stone Avenue North, Apartment D-227, Seattle, Washington 98133, USA
}

\begin{abstract}
Abundance of single, non-attached bacteria and viruses $<110 \mathrm{~nm}$ (likely to have infected bacteria) were determined for surface, interior and bottom ice microhabitats between 66 and $75^{\circ} \mathrm{S}$ in the Ross Sea during the austral summer of 1999. Emphasis was on sites of ice algal blooms, and bacterial abundance was examined with respect to physical characteristics, chlorophyll $a$, phaeophytin and, in particular, microbial communities. Bacterial abundance ranged from $1.5 \times 10^{5}$ to $6.7 \times 10^{6} \mathrm{ml}^{-1}$ melted sample and viral abundance from $6.3 \times 10^{6}$ to $1.19 \times 10^{8} \mathrm{ml}^{-1}$ melted sample over all the microhabitats. Neither bacterial nor viral abundance differed among microhabitats, and bacterial abundance was not related to physical characteristics of the habitats. Although bacterial abundance was positively correlated with chlorophyll $a$ and phaeophytin concentrations, only chlorophyll $a$ was significant in explaining a small $(28 \%)$ degree of the variability in bacterial abundance. Abundance of diatoms, heterotrophic dinoflagellates and other flagellates, however, explained $85 \%$ of the variability in bacterial abundance; these groups were positively correlated with bacterial abundance. Neither viral lysis nor grazing by bacteriovores appeared to be strong controls of bacterial abundance. Community analysis showed that samples were $>90 \%$ similar with respect to abundance of bacteria, viruses, and microeukaryote groups. Distinct clusters could be attributed to different algal bloom stages, with relationships to Phaeocystis spp. blooms being particularly apparent, indicating the strength of algal blooms as processes structuring microbial communities. Microbial communities in Ross Sea summer ice microhabitats could furthermore be viewed within the same general successional sequence characteristic of algal blooms in polar and temperate marine waters.
\end{abstract}

KEY WORDS: Bacteria $\cdot$ Viruses $\cdot$ Pack ice $\cdot$ Algal blooms $\cdot$ Ross Sea

\section{INTRODUCTION}

Bacteria and viruses are significant members of the microbial loop and can reach their greatest abundance and have their greatest roles in association with algal blooms. Although most examples are for diatom blooms in lower latitude waters and mesocosms (e.g. Bratbak et al. 1990, Smith et al. 1995, Riemann et al. 2000), the few studies to date suggest that polar regions are no different (Maranger et al. 1994, Yager et al 2001).
Increases in bacterial abundance, biomass or production during the course of algal blooms occur in Antarctic ice (e.g. Grossi et al. 1984, Kottmeier et al. 1987). High bacterial numbers, biomass or production often occur where ice algal biomass is high (Sullivan \& Palmisano 1984, Kottmeier \& Sullivan 1990, Gleitz et al. 1996, Grossmann et al. 1996).

Ice algal blooms, dominant features of the austral summer pack ice, are noteworthy in Antarctic marine productivity because of timing and distribution (re- 
viewed by Lizotte 2001). In contrast to the water column, where the extent of a bloom can be more easily determined, blooms in pack ice are patchy and can occur in surface, interior and bottom microhabitats (Garrison 1991, Palmisano \& Garrison 1993). Biomass in most ice microhabitats is concentrated into a small volume within brine inclusions. Biomass and abundance of several groups of organisms often equals or greatly exceeds that of similar volumes of the underlying water column (e.g. Sullivan \& Palmisano 1984, Levasseur et al. 1994, Maranger et al. 1994). Therefore, ice microhabitats should be good places to examine microbial interactions during blooms. Knowledge of the viruses and bacteria in different ice microhabitats is needed for an understanding of the Southern Ocean marine ecosystem (Brierley \& Thomas 2002). In addition, the unique Antarctic environment may allow viral studies there to address broad microbial ecological questions (Pearce \& Wilson 2003).

In this study we (1) determine the abundance and distribution of 1 component of the bacterial community, the single unattached bacteria, and of the viruses $<110 \mathrm{~nm}$ likely to have infected bacteria; (2) determine which physical and biological factors affected bacterial abundance; (3) examine abundances of bacteria, viruses and microeukaryotes using community analysis. Sites of summer algal blooms were emphasized, and sampling included a variety of ice microhabitats over a spatial area encompassing $\sim 10^{\circ}$ of latitude along 3 longitudinal transects. This is the first study to consider bacteria in relation to viruses and microeukaryotes of the ice microbial community. Abundance was addressed because the interactions, viral infection of bacteria, algal exudation of compounds affecting bacteria, and grazing by bacteriovores are all densitydependent.

\section{MATERIALS AND METHODS}

Sample collection. We sampled consolidated pack ice and surface slush (ice crystals plus seawater) between 65 and $75^{\circ} \mathrm{S}$ along 3 longitudinal transects and at 1 off-transect site in the Ross Sea during Cruise NBP991 of the RV 'Nathaniel B. Palmer' (Fig. 1). Sampling was from 1 January to 2 February 1999, and stations were at approximately every degree of latitude. One site was sampled on small floes (Stns 001 to 004, 019 to 026). On larger floes, a $150 \mathrm{~m}$ transect representing the floe's surface topographic variability was laid out, and 2 ice cores for physics studies were taken at 3 unridged sites along the transect (e.g. Jeffries et al. 2001). If the cores for ice physics (IP cores) were visibly colored at a site, a bacteria-virus (BV) core and an ice community (IC) core were taken there; otherwise the latter cores were taken from the site closest to the ship. BV and IC cores ( $7.5 \mathrm{~cm}$ diameter) were measured and split into 10 or $20 \mathrm{~cm}$ sections using a saw. IC core sections were placed in plastic jars in an insulated box to minimize temperature changes during transport to the ship. BV core sections were immediately split longitudinally into subsamples, placed in plastic bags and transported to the ship in an insulated box. Temperature was measured at $10 \mathrm{~cm}$ intervals in the field on 1 of the IP cores; the second IP core was placed in an insulated box for shipboard crystal texture and stratigraphy analysis. The BV, IC and IP cores were taken within $50 \mathrm{~cm}$ of each other and were assumed to be replicates.

We collected 2 surface slush samples from different areas on the ice floes than those used as core sites; they were chosen to be representative of surface topography such as level areas or ridges or hummocks. Surface snow and consolidated ice (if present) were removed from a $50 \times 50 \mathrm{~cm}$ area, and slush was scooped into a 41 plastic jar and placed in an insulated box for transport to the ship (Fritsen et al. 2001).

Sample processing and examination. Methods for shipboard processing of cores have been described in detail by Gowing et al. (2002) and those for slush by Gowing (2003). For cores, a 'fast melt plus preservative' regime was used to prevent bacteria and viruses

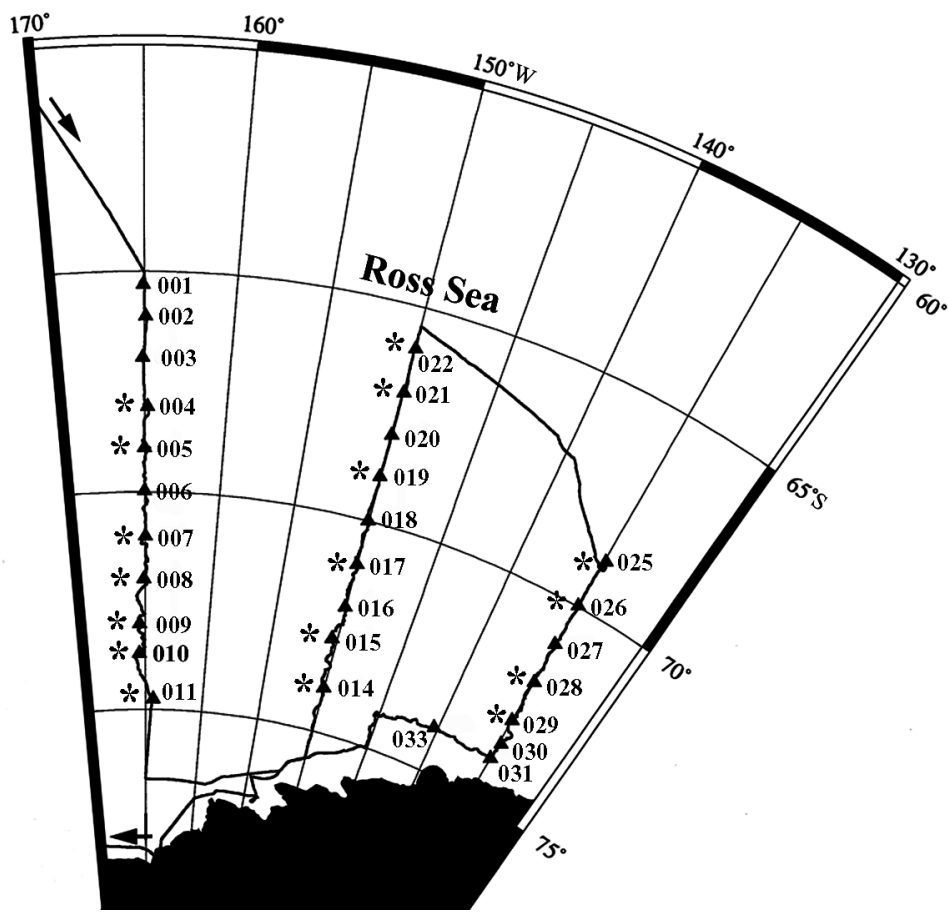

Fig. 1. Cruise track and stations sampled. Station numbers are day of the year, with Stn 001 sampled 1 January 1999 and Stn 033 sampled 2 February 1999. Asterisks indicate stations for which ice community analysis of some samples was made. Image modified from that of C. Masters and T. Schunk 
being grazed by heterotrophs. Core subsections were placed into $200 \mathrm{ml}$ of $0.02 \mu \mathrm{m}$-filtered seawater with borate-buffered paraformaldehyde ( 1\% final concentration) and allowed to melt overnight at room temperature. The total volume was measured to determine the dilution; dilution factors ranged from 0.4 to 1.0. Aliquots for bacterial and viral counts were removed to sterile centrifuge tubes and refrigerated. Slush was allowed to melt at $\sim 4^{\circ} \mathrm{C}$ in the dark before aliquots were fixed with $0.02 \mu \mathrm{m}$-filtered paraformaldehyde fixative. Abundances have been corrected for dilution and are all presented as number $\mathrm{ml}^{-1}$ melted sample.

Filter preparations for bacterial and viral counts using the SYBR Green I light microscopy protocol of Noble \& Fuhrman (1998) were made aboard ship. For each sample, 2 to 4 replicate filters with 0.2 to $2.0 \mathrm{ml}$ of sample were prepared. If less than $2.0 \mathrm{ml}$ of sample were used, the difference was made up with $0.02 \mu \mathrm{m}$-filtered seawater. Solution blanks were prepared at the beginning and end of each batch of samples processed. Filters were mounted in ProLong ${ }^{\mathrm{TM}}$ Antifade medium (Molecular Probes) on slides, frozen at $-80^{\circ} \mathrm{C}$ and air-shipped to the home laboratory. Filters were thawed before counting, and a minimum of 200 bacteria and 200 viruslike particles were counted in 20 fields of view at 1000x using an Olympus BX-60 epifluorescence microscope equipped with an Acridine Orange filter set.

In addition to single and small clusters of bacteria, some samples contained large aggregations of bacteria and/or bacteria attached to diatoms or frustules. Our methods were inadequate for determining the contribution of the latter 2 bacterial populations. Bacteria in large aggregates could not be counted because we did not sonicate sample aliquots to disperse the aggregates for filter preparation at the time of collection. Attached bacteria could not be counted because appropriate amounts of sample for this were not filtered at the time of collection. We recorded the presence of epiphytic bacteria in the samples; this is considered in the 'Discussion'. Our counts are therefore of predominantly single, unattached bacteria, and are an underestimate of the total bacteria.

Abundances of viruses $(<110 \mathrm{~nm}$ capsid diameter) likely to infect bacteria were determined by subtracting the abundance of extracellular large $(\geq 110 \mathrm{~nm}$ capsid size) viruses from the abundance of total (all sizes) viruses determined from the light microscope filter counts. The abundance of larger viruses (assumed to have infected eukaryotes) had been determined from sample aliquots counted using transmission electron microscopy (TEM) as described by Gowing et al. (2002).

Ice communities and environmental characteristics. Sea ice microbial communities were analyzed microscopically from aliquots of a subset (29 samples) of the IC core sections and slush samples as described for slush samples by Fritsen et al. (2001). Chlorophyll a and phaeophytin were determined from aliquots of most core sections and slush samples as described by Fritsen et al. (2001) for slush samples. Salinity of slush samples was measured with a refractometer after samples had melted. Brine salinity of cores was calculated from in situ temperature according to Assur (1958). Ice crystal texture and stratigraphy were determined in the walk-in freezer aboard ship for an IP core from each site according to the methods of Jeffries \& Adolphs (1997). Granular frazil ice and granular infiltration ice (snow ice) were distinguished by stable oxygen isotope analysis as described by Jeffries et al. (2001). Multi-year ice was distinguished from first-year ice mainly by a higher freeboard and rougher surfaces, and in some cases by the presence of superimposed ice 'buried' below the ice surface. In a few instances, abundance of bacteria and viruses was determined for the bottom core section of an IP core after the structural analysis was complete.

Rationale for sample collection and analysis. Sampling was not strictly random because the focus of this project was bacteria, whose abundance was expected to increase during blooms of ice algae. More samples were collected than could be processed at sea. Samples with visible coloration indicative of high algal biomass were given priority for analysis, and other samples were processed as time permitted. Complete cores were not analyzed, and variable numbers ( 0 to 6 core sections) of interior habitats were analyzed at a station. We use the term 'virus', although infectivity was not demonstrated. Strictly defined, these are 'virus-like particles'.

Community analysis. For community analysis we used procedures similar to those described by Field et al. (1982) on the samples with ice community data. Log-transformed abundances were used for 10 groups (bacteria, viruses, diatoms, autotrophic dinoflagellates, Phaeocystis spp. non-motile [colony-associated] cells, Phaeocystis spp. motile cells, other autotrophic flagellates, heterotrophic dinoflagellates, other heterotrophic flagellates, and non-plastidic ciliates). Dissimilarities were calculated between paired samples using the Bray-Curtis measure (Similarity $=1$-Bray-Curtis measure). Single-linkage cluster analysis and multidimensional scaling (MDS) were used to analyze the resulting sample-by-sample matrix (see Field et al. 1982 for details of the procedures).

\section{RESULTS}

\section{Summer pack ice environment}

Ice thickness ranged from 39 to $258 \mathrm{~cm}$. Stns 008 , 017 , and 028 were multi-year floes; the others were 
Table 1. Range of pigment and physical characteristics of the ice microhabitats. FY: first-year ice; MY: multi-year ice; S: snow ice; SI: superimposed ice; F: frazil ice; C: congelation ice; P: platelet ice. Number of samples or core sections are shown in parentheses. Slush samples ranged from 4 to $51 \mathrm{~cm}$ depth; surface core samples ranged from top 5 to $22 \mathrm{~cm}$; interior habitat samples were generally $20 \mathrm{~cm}$ long and ranged from starting depths of 8 to $221 \mathrm{~cm}$; bottom habitat samples, also generally $20 \mathrm{~cm}$ long, ranged from starting depths of 28 to $241 \mathrm{~cm}$. Some of these samples were also used for a study of large viruses, and ranges of characteristics for those samples are given in Gowing (2003)

\begin{tabular}{|c|c|c|c|c|c|}
\hline Habitat & $\begin{array}{l}\text { Chlorophyll a } \\
\qquad\left(\mu \mathrm{g}^{-1}\right)\end{array}$ & $\begin{array}{l}\text { Phaeophytin } \\
\qquad\left(\mu \mathrm{g} \mathrm{l}^{-1}\right)\end{array}$ & $\begin{array}{c}\text { Temperature } \\
\left({ }^{\circ} \mathrm{C}\right)\end{array}$ & $\begin{array}{l}\text { Brine salinity } \\
\quad(\mathrm{psu})\end{array}$ & Ice type \\
\hline Slush & $0.15-120.26(35)$ & $0.03-72.10(35)$ & -1.8 to $-1.0(28)$ & $11.00-32.19(31)$ & \\
\hline \multicolumn{6}{|l|}{ Surface } \\
\hline FY & $2.18-28.34(5)$ & $0.44-13.18(5)$ & -1.6 to $-1.4(5)$ & $25.22-28.72(5)$ & $S(2), F(1), F+S(1), S+S I(1)$ \\
\hline MY & $4.16(1)$ & $0.34(1)$ & $-1.4(1)$ & $25.22(1)$ & $\mathrm{S}+\mathrm{SI}(1)$ \\
\hline \multicolumn{6}{|l|}{ Interior } \\
\hline FY & $1.81-41.88(25)$ & $0.16-7.85(25)$ & -1.9 to $-1.3(24)$ & $20.04-33.92(20)$ & $F(16), C+F(5), C(3)$ \\
\hline MY & $4.33-84.0(9)$ & $0.37-91.08(9)$ & -2.1 to $-1.6(9)$ & $28.72-37.36(9)$ & $F+P(2), F(4), C(3), C+F(2)$ \\
\hline \multicolumn{6}{|l|}{ Bottom } \\
\hline FY & $2.08-71.31(17)$ & $0.23-43.40(17)$ & -1.8 to $-1.3(19)$ & $23.46-30.46(14)$ & $F(11), C(7), C+F(3)$ \\
\hline MY & $13.72(1)$ & $4.2(1)$ & $-1.6(1)$ & $28.72(1)$ & $F(1)$ \\
\hline
\end{tabular}

first-year ice. Ice temperatures ranged from -2.1 to $-1.0^{\circ} \mathrm{C}$, and brine salinity ranged from 11.00 to $37.36 \mathrm{psu}$ within the different ice microhabitats (Table 1). Several ice types were present in the core sections, and chlorophyll $a$ and phaeophytin concentrations ranged over 1 to several orders of magnitude within the microhabitats (Table 1).

\section{Bacterial abundance}

Abundance of single, unattached bacteria ranged from $1.5 \times 10^{5} \mathrm{ml}^{-1}$ in slush to $6.72 \times 10^{6} \mathrm{ml}^{-1}$ in a bottom habitat sample (Table 2, Fig. 2). Abundance of bacteria did not differ between surface core samples and slush (Mann-Whitney $U$-test, $\mathrm{p}>0.05$ ) or among surface (cores and slush combined), interior and bottom habi-

Table 2. Range of abundance of unattached, non-aggregated bacteria and viruses $<110 \mathrm{~nm}$ (likely to have infected bacteria) in the different habitats. N: number of samples

\begin{tabular}{|lccr|}
\hline Habitat & \multicolumn{2}{c|}{ Nos. $\mathrm{ml}^{-1} \times 10^{6}$} & $\mathrm{~N}$ \\
& Min. & Max. & \\
\hline $\begin{array}{l}\text { Surface habitat (cores) } \\
\quad \text { Bacteria }\end{array}$ & 0.18 & 1.68 & 6 \\
$\quad$ Viruses <110 nm & 4.01 & 18.37 & 6 \\
$\quad$ Surface habitat (slush) & & & \\
$\quad$ Bacteria & 0.15 & 5.94 & 38 \\
$\quad$ Viruses <110 nm & 1.25 & 119.00 & 34 \\
Interior habitat (cores) & & & \\
$\quad$ Bacteria & 0.20 & 5.81 & 36 \\
$\quad$ Viruses <110 nm & 0.91 & 53.50 & 34 \\
Bottom habitat (cores) & & & \\
$\quad$ Bacteria & 0.18 & 6.72 & 24 \\
$\quad$ Viruses <110 nm & 0.63 & 15.15 & 22 \\
\hline
\end{tabular}

tats (Kruskal-Wallis test, $\mathrm{p}>0$ 0.05). The mean coefficient of variation for replicate filters for bacterial counts was $21 \%$ for surface cores, $23 \%$ for surface slush, $36 \%$ for interior habitats, and $17 \%$ for bottom habitats.

\section{Viral abundance}

Abundance of viruses $<110 \mathrm{~nm}$ ranged from $6.3 \times$ $10^{5} \mathrm{ml}^{-1}$ in a bottom habitat to $1.19 \times 10^{8} \mathrm{ml}^{-1}$ in surface slush (Table 2, Fig. 2). Viruses were commonly an order of magnitude more abundant than bacteria. Viral abundance did not differ between surface core samples and slush (Mann-Whitney $U$-test, $p>0.05$ ) or among habitats (Kruskal-Wallis test, $\mathrm{p}>0.05$ ). Viruses $<110 \mathrm{~nm}$ made up an average of $97 \%$ or more of the total viral abundance in different ice microhabitats (data not shown). The mean coefficient of variation for replicate filters for total viral counts (from which the abundance of viruses $<110 \mathrm{~nm}$ was determined) was $29 \%$ for surface cores, $29 \%$ for surface slush, $23 \%$ for interior habitats and $26 \%$ for bottom habitats. Viral abundance was significantly positively correlated with bacterial abundance (Spearman's rank correlation coefficient $0.44, \mathrm{p}<0.001$; see Fig. 2). The virus to bacteria ratio (VBR) ranged from 0.7 to 119 over the samples.

\section{Relationship of bacterial abundance to various parameters}

Bacterial abundance showed no relationship to temperature or salinity; bacterial abundance did not differ among the ice types for any habitat, and bacterial abundance did not differ among first-year ice and multi-year ice in interior habitats. Bacterial abundance 


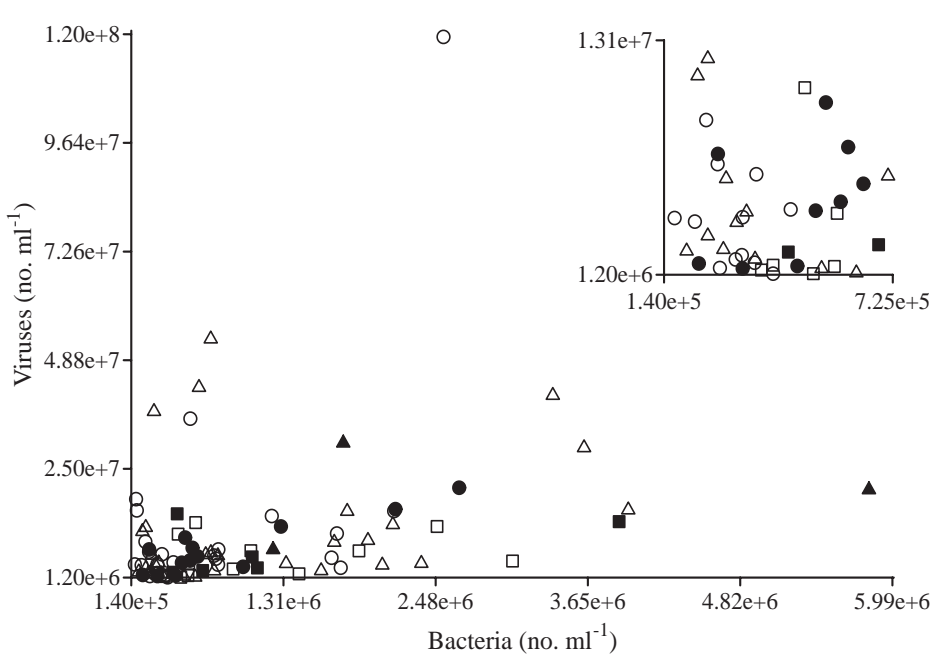

Fig. 2. Bacterial and viral abundance. Note different scales. Inset is expansion of distribution near the lower values. $(\mathrm{O}, \mathbf{0})$ Surface habitats; $(\Delta, \boldsymbol{\Delta})$ interior habitats; $(\square, \boldsymbol{\square})$ bottom habitats; black symbols indicate stations for which ice community data were recorded. Total sample number $=103$

was significantly positively correlated with chlorophyll $a$ and phaeophytin concentrations (Spearman's rank correlation coefficients 0.56 and 0.48 , respectively, $\mathrm{p}<0.001$, for both). A stepwise multiple regression using bacterial abundance as the dependent variable and chlorophyll $a$ and phaeophytin as independent variables showed that chlorophyll a explained $28 \%$ of the variability in bacterial abundance and was the only significant predictor $(\mathrm{p}<0.001)$.

Among the eukaryote groups (diatoms, autotrophic dinoflagellates, non-Phaeocystis autotrophic flagellates, Phaeocystis spp. motile cells, Phaeocystis spp. non-motile [colonial] cells, heterotrophic dinoflagellates, other heterotrophic flagellates, and non-plastidic ciliates) in the 29 samples with ice community data, diatoms (Spearman's rank correlation coefficient 0.51, p < 0.01), motile Phaeocystis spp. cells (Spearman rank correlation coefficient $-0.39, \mathrm{p}<0.05$ ), and heterotrophic dinoflagellates (Spearman's rank correlation coefficient $0.42, \mathrm{p}<0.05$ ) were significantly correlated with bacterial abundance. Using 28 of these samples with complete group data, a stepwise multiple regression was performed using bacterial abundance as the dependent variable and abundances of viruses and the aforementioned eukaryote groups as the independent variables. The resultant model that ex- plained $85 \%$ of the variability in bacterial numbers included diatoms, heterotrophic flagellates and heterotrophic dinoflagellates. Diatoms explained $65 \%$ of the variability, with heterotrophic flagellates adding an additional $13 \%$ and heterotrophic dinoflagellates an additional $7 \%$.

\section{Community analysis}

Single-linkage cluster analysis of the samples showed that all samples entered clusters at $>90 \%$ similarity (dendrogram not shown). Clustering of the samples was consistent using both single-linkage and multidimensional scaling (MDS); samples could be grouped into 3 distinct clusters and 1 outlier (Fig. 3). Samples did not cluster by habitat or by spatial distribution. Table 3 lists the mean abundances of organisms and concentrations of pigments for each cluster as well as the corresponding values for the outlier sample (slush at Stn 011). In general, Cluster 1 was lowest in mean pigments and organisms and Cluster 3 was highest.

\section{DISCUSSION}

\section{Bacterial abundance}

Bacterial abundance in summer Ross Sea ice microhabitats was within ranges reported for similar types of ice sampled at other Antarctic locations during spring and summer (Table 4). Although Grossmann et al. (1996) found a higher maximum abundance of bacteria

Table 3. Mean abundance (nos. $\mathrm{l}^{-1}$ ) of the various groups and mean pigment concentrations $\left(\mu \mathrm{g} \mathrm{l}^{-1}\right)$ in the 3 clusters and values for outlier slush sample. Value of 0 indicates that abundance was below detection limits on filters

\begin{tabular}{|lcccc|}
\hline & $\begin{array}{c}\text { Cluster 1 } \\
(\mathrm{N}=17)\end{array}$ & $\begin{array}{c}\text { Cluster 2 } \\
(\mathrm{N}=7)\end{array}$ & $\begin{array}{c}\text { Cluster 3 } \\
(\mathrm{N}=3)\end{array}$ & $\begin{array}{c}\text { Slush } \\
(\text { Stn 011) }\end{array}$ \\
\hline Groups & & & & \\
Bacteria & $8.7 \times 10^{8}$ & $1.8 \times 10^{9}$ & $3.2 \times 10^{9}$ & $1.3 \times 10^{9}$ \\
Viruses & $6.8 \times 10^{9}$ & $8.3 \times 10^{9}$ & $1.9 \times 10^{10}$ & $1.2 \times 10^{10}$ \\
Diatoms & $5.1 \times 10^{6}$ & $7.1 \times 10^{6}$ & $1.4 \times 10^{7}$ & $1.2 \times 10^{7}$ \\
Autotrophic flagellates & $6.2 \times 10^{5}$ & $3.9 \times 10^{6}$ & $1.1 \times 10^{7}$ & $2.8 \times 10^{4}$ \\
Phaeocystis spp. motile & $1.7 \times 10^{5}$ & 0 & 0 & 0 \\
Phaeocystis spp. non-motile & $3.5 \times 10^{6}$ & $1.1 \times 10^{6}$ & 0 & $9.6 \times 10^{7}$ \\
Autotrophic dinoflagellates & $1.9 \times 10^{4}$ & $2.9 \times 10^{4}$ & $9.7 \times 10^{4}$ & $8.4 \times 10^{4}$ \\
Heterotophic flagellates & $1.2 \times 10^{6}$ & $3.2 \times 10^{6}$ & $7.7 \times 10^{6}$ & $2.8 \times 10^{4}$ \\
Heterotophic dinoflagellates & $5.1 \times 10^{3}$ & $1.1 \times 10^{4}$ & $1.2 \times 10^{4}$ & $2.4 \times 10^{4}$ \\
Ciliates & $2.4 \times 10^{3}$ & $4.7 \times 10^{3}$ & $2.1 \times 10^{3}$ & $2.8 \times 10^{3}$ \\
Pigments & & & & \\
Chlorophyll a & 7.87 & 23.15 & 38.93 & 120.26 \\
Phaeophytin & 1.10 & 16.41 & 58.79 & 23.25 \\
\hline
\end{tabular}




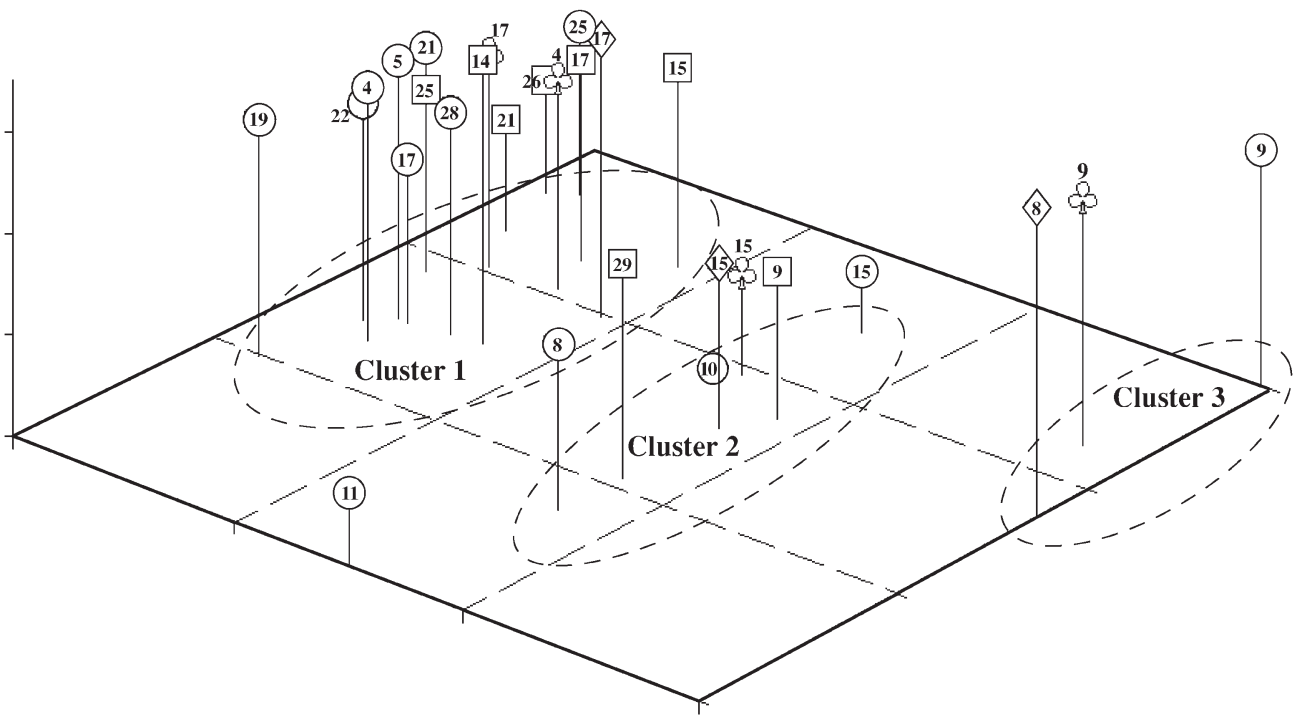

Fig. 3. Similarity plot using 3-dimensional representation of multidimensional scaling (MDS). Axes are arbitrary distance, and distances between samples are proportional to similarity (1 minus Bray-Curtis measure) between the assemblages. In this rotational view most of variability is shown in $x-y$ axis view. (O) surface habitats (slush); $\left(Q_{\mathrm{L}}\right)=$ surface habitats (cores); $(\diamond)$ interior habitats; $(\square)$ bottom habitats; numbers are station numbers in Fig. 1 with initial zeros removed; dashed lines delineate clusters in platelet ice, our bottom microhabitats did not include this specialized ice type, which is not commonly found distant from ice shelves. The overall similar range of abundances suggests that the ice bacterial assemblage has responded in a similar way to algal blooms in a variety of locations during many years.

Although bacterial abundance was positively correlated with chlorophyll $a$, a common proxy for algal biomass, chlorophyll a only explained $28 \%$ of the variability in bacterial abundance. This may be a result of 2 factors. First, ice communities comprise many different algae that may or may not be affecting bacteria directly, although all would contribute to chlorophyll a concentration. Second, bacterial abundance is that of the nonepibacterial component of the bacterial assemblage, whereas chlorophyll a concentration is that of the total microalgal assemblage. This may be less likely to have influenced the relationship for the following reasons. Epiphytic bacteria, generally on Amphiprora-like diatoms, were noted in 4 slush samples, 8 interior habitat samples, and 11 samples from bottom habitats. Although the contribution to total bacterial numbers in the data set is unknown, it is unlikely that the epiphytic bacteria were a significant component of the total bacterial assemblage because they did not occur on a numerically dominant alga. Where ice community data were available, Amphiprora spp. did not dominate, and where epibacteria were observed, they were generally not on every Amphiprora cell. Our pack ice samples, therefore, differed from the diatom assemblages with dominant epibacteria described at McMurdo Sound (Grossi et al. 1984, Sullivan \& Palmisano 1984) and at Davis Station (Archer et al. 1996). Future work should, however, assess epiphytic as well as unattached bacteria for a complete understanding of bacterial abundances.
High concentrations of phaeopigments are indicative of senescent or grazed algae. Bacterial abundances would be expected to be correspondingly high if bacteria were obtaining nutrients exuded by senescent algae or nutrients released as algae were grazed. Bacterial abundance was positively correlated with phaeophytin concentration, but phaeophytin was not significant in the multiple regression for pigments. We have no data on algal senescence during the study. Bacterial abundance was positively correlated with abundance of Cryothecomonas spp. and Telonema spp., grazers on scaled algae (Gowing 2003) (Spearman's rank correlation coefficient $0.41, \mathrm{p}<0.05)$. Other algal grazers were present in all samples, and grazing on diatoms also occurred (M. Gowing pers. obs.). The bulk pigment concentrations, although suggestive of what might have caused variability in bacterial abundance, were not as useful as the abundance of major groups of organisms for interpreting variability in bacterial abundance in the summer pack ice.

Among the autotrophic groups, diatoms were most important in relation to bacterial abundance. Diatoms produce a variety of extracellular polymeric substances (EPS) that appear to influence bacteria, but the exact role of extracellular polymeric substances in mediating diatom-bacteria interactions is unknown (Hoagland et al. 1993). In the ocean, TEP (transparent exopolymeric particles), a type of EPS, often peaks in association with diatom (and Phaeocystis spp.) blooms (reviewed by Passow 2002). Bacteria can utilize TEP, but the degree and importance of such utilization appears to vary (reviewed by Passow 2002). In Arctic winter sea ice, EPS 'correlated positively with bacteria abundance (although no functional relationship could be deduced)' (Krembs et al. 2002, p. 2163). Additional 
Table 4. Abundance of bacteria in ice in Antarctic marine regions in spring and summer. Designations of bottom habitats are not identical because different investigators sampled different core-section lengths

\begin{tabular}{|lcll|}
\hline Habitat & Abundance $\left(\right.$ nos. $\left.\mathrm{ml}^{-1}\right)$ & Location, season & Source \\
\hline Ice habitat & & & \\
Land fast ice (bottom) & $1.02 \times 10^{6}$ (max.) & McMurdo, spring & Sullivan \& Palmisano (1984) \\
Land fast ice (upper) & $0.2-3.6 \times 10^{5}$ & McMurdo, spring & Sullivan \& Palmisano (1984) \\
Pack ice (cores) & $1-30 \times 10^{5}$ & Weddell/Scotia Seas, spring & Miller et al. (1984) \\
Land fast ice (bottom) & $2-8.5 \times 10^{5}$ & McMurdo, spring & Grossi et al. (1984) \\
Land fast (bottom) & $1-5 \times 10^{5}$ & McMurdo, spring and summer & Kottmeier et al. (1987) \\
Land fast (platelet) & $0.05-0.4 \times 10^{6}$ & McMurdo, spring and summer & Kottmeier et al. (1987) \\
Pack ice (cores) & $8.82 \times 10^{5}(\mathrm{avg})$. & Weddell Sea, spring & Kottmeier \& Sullivan (1990) \\
Land fast ice (surface) & $0.3-1.5 \times 10^{6}$ & Adelie Land, spring & Delille \& Rosiers (1995) \\
Land fast ice (bottom) & $0.3-0.4 \times 10^{6}$ & Adelie Land, spring & Delille \& Rosiers (1995) \\
Pack ice (platelets) & $1.5-2 \times 10^{7}(\mathrm{max})$. & Weddell Sea, late summer & Grossmann et al. (1996) \\
Pack ice (infiltration layer) & $2.32 \times 10^{5}, 15.4 \times 10^{5}$ & Weddell Sea, summer & Gleitz et al. (1996) \\
\hline
\end{tabular}

indirect evidence that ice diatoms could stimulate bacterial growth has come from observations that growth of epiphytic bacteria appeared to have been enhanced by association with the diatoms (Grossi et al. 1984, Smith et al. 1989, Archer et al. 1996). Diatoms were abundant and diverse in the Ross Sea summer ice samples (A. H. Gibson et al. unpubl.); laboratory experiments using dominant species might elucidate the effects of diatoms on bacteria.

Neither motile nor non-motile (colony-associated) Phaeocystis spp. cells were significant in explaining variability in bacterial numbers. This was unexpected in the light of literature on bacteriocidal activity of Phaeocystis spp. (Davidson \& Marchant 1992, Montfort et al. 2000; see also discussion in Putt et al. 1994), associations between bacteria and Phaeocystis sp. in McMurdo Sound (Putt et al. 1994), and recent studies suggesting that extracellular polymers of $P$. antarctica (isolated from the Ross Sea) could be utilized by bacteria (Solomon et al. 2003). As most authors have noted, the differences in bacteriocidal properties of Phaeocystis spp. may be due to differences in strains. More than 1 species of Phaeocystis may have been present in our samples: undescribed species of Phaeocystis, whose motile cells differ but whose colonies are indistinguishable, occur in Antarctic sea ice (Marchant \& Thomsen 1994). Most studies of Phaeocystis spp. and bacteria have focused on Phaeocystis spp. colonies. Our finding of a negative correlation between motile Phaeocystis spp. cells and bacterial abundance suggests that research on effects of Phaeocystis spp. should also consider solitary motile cells.

Heterotrophic dinoflagellates and other flagellates were significant (although less so than diatoms) in explaining variability in bacterial abundance. As discussed above, algal grazers would be expected to have a positive effect on bacterial abundance. Relationships between bacteriovores and their prey, however, are likely to be a function of threshold concentrations of bacteria (e.g. Davis \& Sieburth 1984) and to cycle (e.g. Fenchel 1982). Seasonal bacteria-flagellate abundance cycles have been demonstrated, for example, for Arctic coastal lagoon ice (Sime-Ngando et al. 1997). Shorterterm cycles also probably occur, and our data could reflect these. Bacterial abundance was not significantly correlated with abundance of choanoflagellates, grazers on bacteria and smaller particles. The positive relation between bacterial abundance and that of the heterotrophic dinoflagellates and flagellates suggested that, overall, bacteriovores were not controlling bacterial abundance at the time of our sampling.

\section{Role of viruses}

Virus abundance in Ross Sea ice was positively correlated with bacterial abundance, as would be expected, because high bacterial abundance is necessary for transfer of viruses. Virus abundance, however, was not a significant parameter in the multiple regression. The simplest conclusion is that viral abundance was indeed less important than that of the other groups of organisms (diatoms and all heterotrophic flagellates) in explaining variability in bacterial abundance. Other factors that may have contributed to the result should also be noted: (1) Although marine bacteriophages are generally <110 nm (Weinbauer \& Peduzzi 1994), not all viruses $<110 \mathrm{~nm}$ are bacteriophages (e.g. Van Etten et al. 1991, Lawrence et al. 2001). However, if significant numbers of small viruses were infecting major algal groups in any habitat, a positive correlation with chlorophyll a would be expected; this did not occur (Spearman's rank-order correlation test, $\mathrm{p}>0.05$ for all habitats). Furthermore, thin sections of $>30000$ algal cells in these samples were examined in a study of viruses infecting microeukaryotes (Gowing 2003), and 
no algal cells infected with viruses $<110 \mathrm{~nm}$ were observed. Thin sections of thousands of microheterotrophs were also examined, and only 2 cells were infected with viruses $<110 \mathrm{~nm}$, so it is unlikely that large numbers of the small viruses in the samples came from infected eukaryotes. (2) Another consideration related to the viruses counted is the finding by Montanié et al. (2002) that in a temperate coastal pond, dynamics of tailed phages were better linked with bacterial dynamics than was the total viral assemblage (of which generally $>90 \%$ were $<105 \mathrm{~nm}$ ). Whether this is true in Antarctic ice is unknown. (3) We studied unattached, single bacteria, whereas bacteria in dense clusters as well as epibacteria could also be infected with viruses. On the other hand, because viruses must contact bacteria for infection, bacteria in dense clusters might be protected from infection. Epiphytic bacteria have an exopolymeric layer that penetrates the puncta of diatoms (Sullivan \& Palmisano 1984). This substance might protect the epibacteria from viruses; however, some unattached bacteria also have a surface texture suggesting exopolymeric substances (Sullivan \& Palmisano 1984).

Other factors are related to viral dynamics. Viral abundances may be more related to bacterial production than to bacterial abundance (Maranger et al. 1994, Steward et al. 1996, Marchant et al. 2000), and bacterial production in the samples probably differed. Loss rates of viruses (reviewed by Wommack \& Colwell 2000) in the different samples might differ. We have data only on consumption, and thin sections through $>4000$ microheterotrophs revealed no viruses $<110 \mathrm{~nm}$ in food vacuoles (Gowing 2003). Finally, viruses may 'punish' the dominant community members (Thingstad et al. 1993, but see Schwalbach et al. 2004), with high abundances of viruses resulting from lysis of abundant bacteria. Thus the relationship between viral and bacterial abundance would undoubtedly vary over time, and our samples comprised different successional stages of the ice communities (see next subsection).

The VBR (virus-to-bacteria ratio) indicated a varying degree of viral influence from minimal to high. This ratio, generally used to assess the probability of viral control of bacterial populations, changes over time and space (Maranger et al. 1994, Marchant et al. 2000, LaybournParry et al. 2001). Where blooms have been followed in polar areas, the VBR has increased and then decreased for a fast-ice bottom habitat (Maranger et al. 1994) and for surface waters (Yager et al. 2001). Hypotheses for causes of changes in VBR include proliferation of bacteria that are resistant to phage later in the season, reduction of active bacterial cells, or viral infection of algae (Maranger et al. 1994, Yager et al. 2001). In the Ross Sea summer samples, the first 2 possibilities might have contributed to the VBR variability. Additionally, restriction of entry of new viruses through brine channels and changes from lysogenic to lytic cycles in bacteria triggered by external factors such as ultraviolet light might affect the VBR in different ice microhabitats.

Although viral particles have been observed in glacial and accretion ice from the Vostok core (J. Priscu pers. comm.), there is only 1 other published study of predominantly small viruses in ice. Maranger et al. (1994) found viruses in the bottom $4 \mathrm{~cm}$ of Arctic land fast ice ranging from $9 \times 10^{6}$ to $1.5 \times 10^{8} \mathrm{ml}^{-1}$ during the course of the Arctic spring diatom bloom. Minimum viral abundances in Ross Sea ice microhabitats were all lower than the value at the start of the Arctic bloom, and maxima were also lower than the Arctic maximum, although the maximum in surface slush was only slightly lower. The differences could reflect the differences in data from 1 site over time versus data from many sites sampled over 1 mo as well as differences in microbial community composition and dynamics between land fast ice and pack ice. In the Arctic bottom microhabitat, 5 species of pennate diatoms comprised $91 \%$ of algal cell numbers (Levasseur et al. 1994). In contrast, the Antarctic samples comprised microhabitats with diverse algal assemblages with many diatom and non-diatom species at bloom levels (this study; A. H. Gibson unpubl.). This fundamental difference in autotrophs probably would directly and indirectly affect bacterial dynamics and related viral dynamics.

\section{Ice microbial communities}

Despite the wide spatial coverage, the different microhabitats examined, and the month's temporal coverage, the samples were highly (>90\%) similar, based on the abundance of major groups of microorganisms. This suggests that summer algal blooms are processes that structure pack-ice microbial communities. If summer algal blooms in Antarctic pack ice follow the same general course as blooms in other marine environments, different bloom stages should affect bacterial abundance, as shown in Table 5. Reality will be more complex, because different groups and species of algae will bloom at different times, causing the attendant processes and characteristics to overlap, as well as periodic injections of nutrients if viral lysis terminates the blooms (e.g. Castberg et al. 2001). The clusters can be considered within the general successional framework. Cluster 1 appears to represent stages before peaks of algal blooms: average chlorophyll $a$ and phaeophytin concentrations were lowest; average bacterial, viral, diatom, autotrophic flagellate, autotrophic dinoflagellate, heterotrophic dinoflagellate and heterotrophic flagellate abundances were lowest; both motile and non-motile Phaeocystis spp. cells were pre- 
Table 5. Changes in factors influencing bacterial abundance during course of an algal bloom. Table combines results from timeseries studies by Davidson \& Marchant (1992), Maranger et al. (1994), Putt et al. (1994), Sime-Ngando et al. (1997), Castberg et al. (2001), Yager et al. (2001) and Monticelli et al. (2003)

\begin{tabular}{|c|c|c|c|}
\hline Bloom stage & $\begin{array}{l}\text { Algal biomass } \\
\text { or abundance }\end{array}$ & $\begin{array}{l}\text { Bacterial } \\
\text { abundance }\end{array}$ & $\begin{array}{l}\text { Dominant characteristics/ } \\
\text { processes with respect to bacteria }\end{array}$ \\
\hline Early & Low & Low & Low substrate \\
\hline Mid & Moderate & Moderate & Increasing substrate, low mortality \\
\hline Peak & High & High & High substrate, high algal effects, predation increasing, viral lysis beginning \\
\hline Post-peak & High & Highest & High substrate, high algal effects, high predation, high viral lysis \\
\hline Late & Declining & Declining & High substrate, predation declining, viral lysis declining \\
\hline
\end{tabular}

sent, a condition that occurs before the peak of water column blooms of $P$. antarctica in the Ross Sea (Smith et al. 2003). Cluster 2 can be interpreted as closest to the peak of a bloom of Phaeocystis spp., with a high mean abundance of non-motile cells and no detectable motile cells; mean concentrations of pigments and mean abundances of bacteria, viruses and some autotroph and heterotroph groups are intermediate. Cluster 3 lacked any detectable Phaeocystis spp. cells, which could be a result of patchiness in bloom occurrence and the fact that the cluster comprised only 3 samples; Cluster 3 appeared to be a late stage of diatom and autotrophic flagellate blooms because of the high mean phaeophytin concentration coupled with the high mean abundances of diatoms, autotrophic flagellates, heterotrophic flagellates, bacteria, and viruses. The outlier slush sample can be interpreted as close to or an actual bloom stage of Phaeocystis spp. because of its abundant non-motile cells; diatoms were also blooming, and chlorophyll a concentration was highest in this data set (Table 3). Bacterial and viral abundance was high, and the phaeophytin concentration indicates grazing and/or some algal senescence. The community analysis and abundance relationships suggest that bacterial and viral dynamics in ice microhabitats during the austral summer may be similar to the complex interactions during algal blooms in marine temperate and polar water columns.

Acknowledgements. We thank C. Venn, J. N. King, J.-L. Tison, S. L. Coale, D. Neenan, and S. Nihashi for help in the field and B. E. Riggs and L. C. Van De Werfhorst for help in the laboratory. We thank J. Barnes and the Antarctic Support Associates team, Captain J. Borkowski and the officers and crew of the 'N. B. Palmer' and our NBP99-1 colleagues for a successful cruise. We appreciated advice on light microscope preparations and sharing of protocols from J. Fuhrman, D. Bird, G. Steward, and C. Suttle. We thank R. T. Hinegardner for discussions and anonymous reviewers for helpful suggestions including the use of additional statistical analyses. This work was supported by National Science Foundation grants OPP9725136 to M.M.G., OPP9614201 to D.L.G. and M.M.G., OPP9614844 to M.O.J. and S. Li, and OPP9814972 to C.H.F. Interpretations and conclusions are those of D.L.G. and do not imply the endorsement of the National Science Foundation.

\section{LITERATURE CITED}

Archer SD, Leakey RJG, Burkill PH, Sleigh MA, Appleby CJ (1996) Microbial ecology of sea ice at a coastal Antarctic site: community composition, biomass and temporal change. Mar Ecol Prog Ser 135:179-195

Assur A (1958) Composition of sea ice and its tensile strength. In: Thurston W (ed) Arctic sea ice. Natl Res Counc Publ. 598. National Academy of Sciences, Easton, MD, p 106-138

Bratbak G, Heldal M, Norland S, Thingstad TF (1990) Viruses as partners in spring bloom microbial trophodynamics. Appl Environ Microbiol 56:1400-1405

Brierley AS, Thomas DN (2002) Ecology of Southern Ocean pack ice. Adv Mar Biol 43:171-276

Castberg T, Larsen A, Sandaa RA, Brussaard CPD and 5 others (2001) Microbial population dynamics and diversity during a bloom of the marine coccolithophorid Emiliania huxleyi (Haptophyta). Mar Ecol Prog Ser 221:39-46

Davidson AT, Marchant HJ (1992) Protist abundance and carbon concentration during a Phaeocystis-dominated bloom at an Antarctic coastal site. Polar Biol 12:387-395

Davis PG, Sieburth J McN (1984) Estuarine and oceanic microflagellate predation of actively growing bacteria: estimation by frequency of dividing-divided bacteria. Mar Ecol Prog Ser 19:237-246

Delille D, Rosiers C (1995) Seasonal changes of Antarctic marine bacterioplankton and sea ice bacterial assemblages. Polar Biol 16:27-34

Fenchel T (1982) Ecology of heterotrophic microflagellates. IV. Quantitative occurrence and importance as bacterial consumers. Mar Ecol Prog Ser 9:35-42

Field JG, Clarke KR, Warwick RM (1982) A practical strategy for analysing multispecies distribution patterns. Mar Ecol Prog Ser 8:37-52

Fritsen CH, Coale SL, Neenan DR, Gibson AH, Garrison DL (2001) Biomass, production and microhabitat characteristics near the freeboard of ice floes in the Ross Sea, Antarctica, during the austral summer. Ann Glaciol 33:280-286

Garrison DL (1991) Antarctic sea ice biota. Am Zool 31:17-33

Gleitz M, Grossmann S, Scharek R, Smetacek V (1996) Ecology of diatom and bacterial assemblages in water associated with melting summer sea ice in the Weddell Sea, Antarctica. Antarctic Sci 8:135-146

Gowing MM (2003) Large viruses and infected microeukaryotes in Ross Sea summer pack ice habitats. Mar Biol 142: 1029-1040

Gowing MM, Riggs BE, Garrison DL, Gibson AH, Jeffries MO (2002) Large viruses in Ross Sea autumn pack ice habitats. Mar Ecol Prog Ser 241:1-11

Grossi SM, Kottmeier ST, Sullivan CW (1984) Sea ice microbial communities. III. Seasonal abundance of microalgae 
and associated bacteria, McMurdo Sound, Antarctica. Microb Ecol 10:231-242

Grossmann S, Lochte K, Scharek R (1996) Algal and bacterial processes in platelet ice during late austral summer. Polar Biol 16:623-633

Hoagland KD, Rosowski JR, Gretz MR, Roemer SC (1993) Diatom extracellular polymeric substances: function, fine structure, chemistry, and physiology. J Phycol 29:537-566

Jeffries MO, Adolphs U (1997) Early winter ice and snow thickness distribution, ice structure and development of the western Ross Sea pack ice between the ice edge and the Ross Ice Shelf. Antarct Sci 9:188-200

Jeffries MO, Krouse HR, Hurst-Cushing B, Maksym T (2001) Snow ice accretion and snow cover depletion on Antarctic first-year ice floes. Ann Glaciol 33:51-60

Kottmeier ST, Sullivan CW (1990) Bacterial biomass and production in pack ice of Antarctic marginal ice edge zones. Deep-Sea Res I 37:1311-1330

Kottmeier ST, Grossi SM, Sullivan CW (1987) Sea ice microbial communities. VIII. Bacterial production in annual sea ice of McMurdo Sound, Antarctica. Mar Ecol Prog Ser 35: 175-186

Krembs C, Eicken H, Junge K, Deming JW (2002) High concentrations of exopolymeric substances in Arctic winter sea ice: implications for the polar ocean carbon cycle and cryoprotection of diatoms. Deep-Sea Res I 49:2163-2181

Lawrence JE, Chan A, Suttle CA (2001) A novel virus (HaNIV) causes lysis of the toxic bloom-forming alga Heterosigma akashiwo (Raphidophyceae). J Phycol 37:216-222

Laybourn-Parry JA, Hofer JS, Sommaruga R (2001) Viruses in the plankton of freshwater and saline Antarctic lakes. Freshw Biol 46:1279-1287

Levasseur M, Gosselin M, Michaud S (1994) A new source of dimethylsulfide (DMS) for the arctic atmosphere: ice diatoms. Mar Biol 121:381-387

Lizotte M (2001) The contributions of sea ice algae to Antarctic marine primary production. Am Zool 41:57-73

Maranger R, Bird DF, Juniper SK (1994) Viral and bacterial dynamics in Arctic sea ice during the spring algal bloom near Resolute, N.W.T., Canada. Mar Ecol Prog Ser 111:121-127

Marchant HJ, Thomsen HA (1994) Haptophytes in polar waters. In: Green JC, Leadbeater BSC (eds) The haptophyte algae. Clarendon Press, Oxford, p 209-228

Marchant HJ, Davidson A, Wright S, Glazebrook J (2000) The distribution and abundance of viruses in the Southern Ocean during spring. Antarctic Science 12:414-417

Miller MA, Krempin DW, Manahan DT, Sullivan CW (1984) Growth rates, distribution, and abundance of bacteria in the ice-edge zone of the Weddell and Scotia Seas, Antarctica. Antarct J US 19:103-105

Montanié H, Hartmann HJ, Crottereau C, Trichet C (2002) Virus-like particle analysis in a seston-rich coastal pond using transmission electron microscopy. Aquat Microb Ecol 28:105-115

Montfort P, Demers S, Levasseur M (2000) Bacterial dynamics in first year sea ice and underlying seawater of Saroma-ko Lagoon (Sea of Okhotsk, Japan) and Resolute Passage (High Canadian Arctic): inhibitory effects of ice algae on bacterial dynamics. Can J Microbiol 46:623-632

Editorial responsibility: Otto Kinne (Editor), Oldendorf/Luhe, Germany
Monticelli LS, La Ferla R, Maimone G (2003) Dynamics of bacterioplankton activities after a summer phytoplankton bloom period in Terra Nova Bay. Antarct Sci 15:85-93

Noble RT, Fuhrman JA (1998) Use of SYBR Green I for rapid epifluorescence counts of marine viruses and bacteria. Aquat Microb Ecol 14:113-118

Palmisano AC, Garrison DL (1993) Microorganisms in Antarctic sea ice. In: Friedmann IE (ed) Antarctic microbiology. Wiley-Liss, New York, p 167-218

Passow U (2002) Transparent exopolymer particles (TEP) in aquatic environments. Prog Oceanogr 55:287-333

Pearce DA, Wilson WH (2003) Viruses in Antarctic ecosystems. Antarct Sci 15:319-331

Putt M, Miceli G, Stoecker DK (1994) Association of bacteria with Phaeocystis sp. in McMurdo Sound, Antarctica. Mar Ecol Prog Ser 105:179-189

Riemann L, Steward GF, Azam F (2000) Dynamics of bacterial community composition and activity during a mesocosm diatom bloom. Appl Environ Microbiol 66:578-587

Schwalbach MS, Hewson I, Fuhrman J (2004) Viral effects on bacterial community composition in marine plankton microcosms. Aquat Microb Ecol 34:117-127

Sime-Ngando T, Juniper SK, Demers S (1997) Ice-brine and planktonic microheterotrophs from Saroma-ko Lagoon, Hokkaido (Japan): quantitative importance and trophodynamics. J Mar Syst 11:149-161

Smith DC, Steward GF, Long RA, Azam F (1995) Bacterial mediation of carbon fluxes during a diatom bloom in a mesocosm. Deep-Sea Res II 42:75-97

Smith RE, Clement P, Cota GF (1989) Population dynamics of bacteria in Arctic sea ice. Microb Ecol 17:63-76

Smith WOS Jr, Dennett MR, Mathot S, Caron DA (2003) The temporal dynamics of the flagellated and colonial stages of Phaeocystis antarctica in the Ross Sea. Deep-Sea Res II 50: 605-617

Solomon CM, Lessard EJ, Keil RG, Foy MS (2003) Characterization of extracellular polymers of Phaeocystis globosa and P. antarctica. Mar Ecol Prog Ser 250:81-89

Steward GF, Smith DC, Azam F (1996) Abundance and production of bacteria and viruses in the Bering and Chukchi Seas. Mar Ecol Prog Ser 131:287-300

Sullivan CW, Palmisano AC (1984) Sea ice microbial communities: distribution, abundance, and diversity of ice bacteria in McMurdo Sound, Antarctica, in 1980. Appl Environ Microbiol 47:788-795

Thingstad TF, Heldal M, Bratbak G, Dundas I (1993) Are viruses important partners in pelagic food webs? Trends Ecol Evol 8:209-213

Van Etten JL, Lane LC, Meints RH (1991) Viruses and viruslike particles of eukaryotic algae. Microbiol Rev 55:586-620

Weinbauer MG, Peduzzi P (1994) Frequency, size and distribution of bacteriophages in different marine bacterial morphotypes. Mar Ecol Prog Ser 108:11-20

Wommack KE, Colwell RR (2000) Virioplankton: viruses in aquatic ecosystems. Microbiol Mol Biol Rev 64:69-114

Yager PL, Connelly TL, Mortazavi B, Wommack KE, Bano N, Bauer JE, Opsahl S, Hollibaugh JT (2001) Dynamic bacterial and viral response to an algal bloom at subzero temperatures. Limnol Oceanogr 46:790-801

Submitted: April 30, 2003; Accepted: June 8, 2004

Proofs received from author(s): September 13, 2004 